\title{
GETTING INTO THE GAME: THE TRICKSTER IN AMERICAN ETHNIC FICTION
}

\section{Helen Lock \\ University of Louisiana at Monroe}

Trickster novels, especially those by Gerald Vizenor and Maxine Hong Kingston, can be used to destabilize and undermine ethnic stereotypes. As many studies show, the trickster him/herself cannot be stable and thus resists the limitations of definition as the embodiment of ambiguity. Both insider and outsider, s/he plays with the whole concept of "sides" so as to erase the distinction between them. The trickster plays the game, including the game of language, in order to break and exploit its rules and thus destabilizes linguistic markers. Kingston and Vizenor use their novels to subvert the rules of the linguistic game and free perception from stereotypic rigidity. Perceptions of race and ethnicity are frequently codified in the form of stereotypes with which we are all familiar. Once established, they, of course, prove remarkably difficult to dismantle however false or misleading they might be with regard to the race or ethnicity in question; and thus they continue to exacerbate the social tensions with which we are equally familiar. Ethnic American literature has frequently addressed this issue; in this essay I intend to look at one narrative strategy which is specifically designed to question, challenge, exploit, and even manipulate perception. 


\section{Ethnic Studies Review Volume 26: 1}

It is not hard to find examples, especially in recent ethnic American literature, of a preoccupation with racial and ethnic stereotypes and their consequences. Examples can be taken from Chitra Banerjee Divakaruni's The Mistress of Spices in which ethnic preoccupations nearly sabotage romance, from Toni Morrison's "Recitatif" and Paradise in which ethnic preconceptions can sabotage the reader, or from Maxine Hong Kingston's Tripmaster Monkey, whose narrator is so preoccupied with race and racial markings that he is in some danger of sabotaging himself. He does not, however, and the way in which Kingston's trickster hero turns the sabotage around makes the novel one useful focal point along with Gerald Vizenor's Griever, Paul Beatty's The White Boy Shuffle, and other recent novels, to demonstrate the function of the trickster novel in destabilizing and confounding ethnic stereotypes.

As seminal works by Paul Radin and Lewis Hyde have shown, the trickster him/herself ${ }^{1}$ cannot be stable and thus resists the limitations of definition. According to Radin,

Trickster is at one and the same time creator and destroyer, giver and negator, he who dupes others and who is always duped himself. He wills nothing consciously. He possesses no values, moral or social, is at the mercy of his passions and appetites, yet through his actions all values come into being" (xxiii).

Lewis Hyde adds to this:

[T] he best way to describe trickster is to say simply that the boundary is where he will be found-sometimes drawing the line, sometimes crossing it, sometimes erasing or moving it, but always there, the god of the threshold in all its forms" (7-8).

Similarly, William Willeford-in a discussion of the fool, of which he says the trickster is "a special mythological form" (132)-notes, like Hyde, that sometimes the boundary-crosser actually creates boundaries:

Since the disorder of which he [the fool] is the spirit is largely contained in his show, he serves as the boundary of which he is the enemy; and in doing this, he sometimes even demonstrates an authority proper to the central figure of the established order . . . . 
Nevertheless, he is often regarded as a usurper with no right to be where he is in the ordered world (133). Willeford goes on, with particular reference to Charlie Chaplin's A Dog's Life (1918), to describe the fool's comic negotiations back and forth across this social border, between order and chaos:

$\mathrm{He}$ is impelled by the dynamism of chaos; they [Chaplin's cop antagonists] are impelled by what they take to be the necessity of reinforcing the wall against the outside and neutralizing what has broken through it into the world they govern (135).

The comedy lies in the juxtaposition of the fool and the boundary-keepers; for the former, boundaries are arbitrary, so that the latter are continually required to renegotiate definitions of the borderland.

If the fool's spirit of disorder "is largely contained in his show," however, the trickster's is not. The primary distinction between them is that the trickster actually is everything the fool is only playing at being. Particularly for the trickster's modern literary incarnations, in penetrating and shifting the boundaries there is something at stake of the highest consequence, and it lies beyond the delimited world of play-or, indeed, of fiction-since one of his functions is to erase the boundary that separates play from "real" life. The trickster thus embodies "a method by which a stranger or underling can enter the game, change its rules, and win a piece of the action .... No wonder trickster is sometimes the god of those who do not control their own lot in life, but hope to" (Hyde 204, 215).

This reminder of the fundamental disruptive ambiguity of the trickster brings me directly to the American trickster novel, which in recent years has typically been produced by writers of dual ethnic or cultural backgrounds, unlike the archaic storytellers who engendered the archetypal trickster narratives. Gerald Vizenor, for example, the writer of Native American and European ancestry, centers each of his novels on a mixedblood, or (to use his word) "crossblood," trickster, brought into being through what Vizenor calls "trickster discourse." A description of its governing principles can be found in the prologue, "Tricksters and Transvaluation," to The Trickster of Liberty (1988): 


\section{Ethnic Studies Review Volume 26: 1}

The trickster is comic nature in a language game, not a real person or 'being' in the ontological sense. Tribal tricksters are embodied in imagination and liberate the mind; an androgyny, she would repudiate translations and imposed representations, as he would bare the contradictions of the striptease $(x)$.

As the trickster is thus a linguistic being (as constituent of a language game, the trickster is not "playing," he is "being played" by his narrator), trickster discourse reflects this by using language in disruptive, deconstructive ways, taking aim at the kind of linguistically-encoded supposed verities that in Darkness in Saint Louis Bearheart (1978; rpt. in 1990 as Bearheart: The Heirship Chronicles) Vizenor calls "terminal creeds." These "creeds" include those that demarcate ethnic boundaries by posting exclusionary markers; for example, Louis Owens says this of Bearheart:

[t]he principal target of the fiction is . . . the sign 'Indian,' with its predetermined and well-worn path between signifier and signified. Vizenor's aim is to free the play between these two elements, to liberate 'Indianness,' and in so doing to free Indian identity from the epic, absolute past that insists upon stasis and tragedy for Native Americans (231).

By containing both sides of the boundary within his own inherent duality, the crossblood trickster changes the meaning of the definitions and disrupts the rules of the game. As Henry Louis Gates, Jr., has said, the "discursive universe" (or as Vizenor would put it, language game) inhabited by the West African Signifying Monkey and other tricksters is "absolutely dependent on the play of differences" (53). The trickster's trickery consists in exploiting these differences, by reinterpreting, changing, and inverting meaning, shifting the boundaries between literal and figurative, switching codes, inverting conventions: generally, moving the goalposts, so that at every moment the game has a new configuration.

It is relevant in this context that Hyde describes the trickster as having, like the crossblood, or anyone of blended cultural heritage, no established "way" of conducting himself, "no fixed instinctual responses.... Having no way, he is dependent on 
others whose manner he exploits, but he is not confined to their manner and therefore in another sense he is more independent" (45). Hence, as a linguistic being, he exploits yet is ultimately independent of the traditional connections between signifier and signified. "Language is a tool assembled by creatures with 'no way' trying to make a world that will satisfy their needs; it is a tool those same creatures can disassemble if it fails them" (Hyde 75). Thus Griever, the trickster hero of Vizenor's Griever: An American Monkey King in China (1987), finds ways to dismantle overdetermined linguistic connections:

Now and then his trickeries on rough paper are cornered in popular cliches and institutions, abused by those who vest their personal power in labels and tickets to the main events. When this happens... he pleats and doubles, shrouds and veronicas, creases photographs, folds brochures, dictionaries, and menus, to weaken the plane realities" (201-2).

In other words, he shifts and disguises the boundaries, undoes and redraws the traditional connections.

Griever is the story of a reservation-born crossblood American trickster's deliberately disruptive (and, to many of the other characters, outrageous) sojourn at a university in the People's Republic of China. Also referred to as "Monkey" and "mind monkey," Griever recalls-is to some extent another version of-the ancient Chinese trickster the Monkey King ("the Monkey of the Mind"), who accompanied the Buddhist monk Tripitaka on a pilgimage and was responsible for eating the Peaches of Immortality that were sacred to the Taoist deities: a story whose earliest literary retelling is the sixteenth-century Chinese novel, The Journey To The West. The same trickster tale informs the novel, Tripmaster Monkey (1987), by Chinese American writer Maxine Hong Kingston. Jeanne Rosier Smith suggests that the novel's narrator "resembles Kuan Yin, the Goddess of Mercy who supervises Monkey's journey" (59), and thus, interwoven with the hero's male voice, "allows the author an androgynous point of view" (63): an appropriate trickster stance, reminding us that the teller of a trickster tale-the person who incarnates the trickster in words and engenders his tricks-is inevitably a trickster her/himself. 


\section{Ethnic Studies Review Volume 26: 1}

The hero of Tripmaster Monkey, a sixties Berkeley graduate whose evocative name, Wittman Ah Sing, underscores his cultural duality, declares, "I am really: the present-day U.S.A. reincarnation of the King of the Monkeys" (33). His episodic adventures, which cause havoc in toy stores, unemployment offices, and parties, are permeated throughout with meditations on racial and cultural stereotypes ("Do Jews look down on men who use bobby pins to hold their yarmulkes on?" [74]; "[T]hey don't hire and cast Blacks, so Russ Tamblin [in West Side Story], as Riff the gangleader with kinky hair, indicates Blackness, right?" [71]; "The way Hop Sing shuffles, I want to hit him" [320]), especially with regard to Chinese Americans. His story culminates in the performance of his lengthy play based on ancient Chinese legend (but including such characters as Rudyard Kipling and John Wayne), designed to reflect the lengthy and continuous structure of traditional Chinese theatre, and performed by a multi-ethnic cast, all of whom are Americans. Toward the performance's conclusion, Wittman-having recognized the emptiness of the stereotypes that obsessed him-challenges the critics' cliched response and the audience's assumptions: "There is no East here. West is meeting West. This was all West. All you saw was West. This is Journey In The West" (308). Rejecting Orientalism or any other such terminal creed, the trickster disproves the notion that never the twain shall meet by dismantling the "sides" that the twain supposedly demarcate. ("They wouldn't write a headline for Raisin in the Sun: 'America meets Africa'" [307].) Mediating between and challenging the boundaries of cultures and ethnicities, Kingston's trickster underscores their contingency, a point echoed by another child of two cultures, Richard Rodriguez, in his memoir, Hunger of Memory (1982): "[M]y complexion assumes its significance from the context of my life. My skin, in itself, means nothing" (137). Commenting on this passage, Lewis Hyde notes, "This is the insight that comes to all boundary-crossers-immigrants in fact or immigrants in time-that meaning is contingent and identity fluid, even the meaning and identity of one's own body" (172). The trickster here, then, reveals himself as one who has no fixed "way" but can transform himself contextually to any "way."

Hence the vein of miscegenation that runs through many 
such trickster novels, emblematic as it is of shifting the boundaries to reveal the contingent meaning of "skin." Underpinning American racism, says Hyde, "is the injunction against miscegenation, for if the races can mix, how can they be essentially different?" (353). Wittman, for one, discovers that they are not, necessarily, when yet another of the stereotypes that obsess him is shown to be meaningless:

I had thought that one advantage of marrying a white chick would be that she'd say, 'I love you,' easily and often. It's part of their culture. . . No skin off their pointy noses to say 'I love you.' But all I'm getting is, 'I'm not in love with you, Wittman' (339).

They celebrate their marriage anyway, having revised their mutual expectations. Griever's sexual encounters are more varied: "a holosexual mind monkey," he is described in retrospect as "the cock of the walk, and he seem[s] to love the whole wide world" (21). His most significant liaison is with his Chinese lover, Hester Hua Dan, who drowns, and with whose relative, Kangmei, he flies to freedom at the novel's end ("a mixedblood barbarian trickster in an opera coat" and "a mixedblood blonde who speaks Chinese" [233]), but his earlier encounter with the white American, Sugar Dee, is perhaps the ultimate example of raceand gender-blending, as in the course of it he actually becomes her: "He became a woman there beneath her hair" (55): the trickster as hermaphrodite, both skin- and form-changing.

In all this the mixedblood tricksters discussed so far exemplify what Warwick Wadlington calls the "fertile idea of 'neitherboth.'

That is, the Trickster is a means of identifying, and more importantly, experiencing, an elusive fullness that is not 'either-or' (as, either good or evil, either cunning or stupid) nor exactly 'both-and,' but a margin that is in a sense both the sectors it lies between yet truly, completely, neither (19).

This is the space carved out by those with no definitive "way," trying, as Hyde says, "to make a world that will satisfy their needs" (75). Those needs require the transformation of existing rigid and discrete definitions not into a simple combination but into something entirely new, in which former oppositions are 


\section{Ethnic Studies Review Volume 26: 1}

subsumed. Former divided selves are dismantled and reconstituted, through linguistic disruption of traditional markers, as integrated, complex selves. As Wadlington goes on to say, "the Trickster's marginal nature does not so much synthesize oppositions, as serve as a referent for them: it is what oppositions seek to capture" (19). Unlike the premodern trickster, then, "whose chief and most alarming characteristic [was] his unconsciousness" (Jung, "Trickster" 203), these modern tricksters are quite self-aware, as Wittman becomes. As Hyde says, from the "somewhat witless [premodern] character"comes "a more sophisticated trickster" (171), who can distinguish between sign and signified, and who can use the distinction consciously to redraw his world.

The linguistic tricksters on which I have focused are only some of the most obvious examples. There are many other Native American, Asian American, Latino/a American, and other ethnic American tricksters, including tricksters of EuropeanAmerican descent. Tricksters also abound in African American literature, taking their cue from the ancient Yoruba tricksters, Eshu and Legba, whose manipulation of language is foregrounded in Robert D. Pelton's book The Trickster in West Africa: A Study of Mythic Irony and Sacred Delight (1980), in which he calls them "writers of destiny" and emphasizes "Legba's mastery over the inner language of the human self" (113). Henry Louis Gates, Jr., further describes Eshu as "a figure of double duality, of unreconciled opposites, living in harmony. . . . the epitome of paradox" (30) who has the "capacity to reproduce himself ad infinitum" (37). Gates' book, The Signifying Monkey: A Theory of African-American Literary Criticism (1988), charts the influence of the related African-American trickster the Signifying Monkey on the African American vernacular tradition, oral and written--the focus again being on the trickster as a linguistic being or force. Indeed, given the double-consciousness (to use W.E.B. DuBois' well-known phrase) that has informed the history of this tradition, it is hardly surprising that the ambiguous double-natured (and multivalent) trickster should so often have been chosen as the medium of its expression. He appears, for example, in Ralph Ellison's Invisible Man (1952), not just as the transformative Rinehart but also as the ambiguous, unnamed narrator; 
he is ubiquitous in the novels of Ishmael Reed, both as character and as informing spirit; he recently appeared in Paul Beatty's novel, The White Boy Shuffle (1996), the career of whose African American protagonist, Gunnar Kaufman (a name again indicative of his blended heritage), surpasses Wittman's in its capacity to wreak havoc: as he says on the first page,

If a movie mogul buys the film rights to my life, the TV Guide synopsis will read: 'In the struggle for freedom, a reluctant young poet convinces black Americans to give up hope and kill themselves in a climactic crash ' $n$ ' burn finale. Full of laughs and high jinks. Some violence and adult language' (1).

(Gunnar also echoes Wittman's and Griever's miscegenation, in his marriage to a mail-order Japanese bride, who arrives via UPS.) More subtle in approach (not that tricksters are under any obligation to be subtle) is Toni Morrison's short story about two girls of different but unspecified races, "Recitatif" (1983), which disrupts and confounds received notions of ethnic markers to the extent that it becomes a prime example of the kind of narrative of which Lewis Hyde says, "The trickster in the narrative is the narrative itself" (267).

This is true to some extent, though, of all trickster narratives, given that the trickster is an imaginative and linguistic being, and as such seems most at home in writings generated in the context of duality and ambiguity, especially as a consequence of ethnic and cultural identity.

This ancient penetrator of boundaries continues to inhabit the literary imaginations of modern boundary crossers and erasers, disrupting the game of language to confound and transform its traditional fixities and expectations, freeing the possibilities of perception by subverting the rules of the game. In this, the trickster engages in an imaginative pursuit of rights: the right not to be limited, not to be prejudged, not to be restricted, not to be static, the right not to be left out of the game-and, of course, being a trickster, the right to be all of these if one chooses.

\section{NOTE}

1. Trickster and gender is a related, and highly vexed, issue, which is unfortunately beyond the scope of this essay. For largely opposing views, see Hyde's appendix "Trickster and Gender" (335-343) and 


\section{Ethnic Studies Review Volume 26: 1}

Landay. The salient point, however, seems to be that tricksters are culturally specific.

\section{WORKS CITED}

Beatty, Paul. The White Boy Shuffle. New York: Houghton Mifflin, 1996.

Divakaruni, Chitra Banerjee. The Mistress of Spices. New York: Anchor, 1997.

Ellison, Ralph. Invisible Man. 1952. New York: Vintage, 1973.

Gates, Henry Louis, Jr. The Signifying Monkey: A Theory of African American Literary Criticism. New York: OUP, 1988.

Hyde, Lewis. Trickster Makes This World: Mischief, Myth, and Art. New York: Farrar, Strauss and Giroux, 1998.

The Journey to the West. Trans. and ed. Anthony C. Yu. 4 vols. Chicago: U of Chicago P, 1977-83.

Jung, C. G. "On the Psychology of the Trickster Figure." Trans. R.F.C. Hull. Radin 195-211.

Kingston, Maxine Hong. Tripmaster Monkey: His Fake Book. New York: Vintage, 1987.

Landay, Lori. Madcaps, Screwballs, and Con Women: The Female Trickster in American Culture. Philadelphia: U of Penn P, 1998.

Morrison, Toni. "Recitatif." Confirmation. Ed. Amiri and Amina Baraka. New York: Morrow, 1983. Rpt. in The Norton Anthology of American Literature. Vol. 2. 5th ed. Ed. Nina Baym et al. New York: Norton, 1998. 2077-92.

Owens, Louis. Other Destinies: Understanding the American Indian Novel. Norman, OK: U of Oklahoma P, 1992.

Pelton, Robert D. The Trickster in West Africa: A Study of Mythic Irony and Sacred Delight. Berkeley: U of California P, 1980.

Radin, Paul. The Trickster: A Study in American Indian Mythology. 1956. New York: Schecken, 1971. 


\section{Lock-The Trickster}

Rodriguez, Richard. Hunger of Memory: The Education of Richard Rodriguez. New York: Bantam, 1982.

Smith, Jeanne Rosier. Writing Tricksters: Mythic Gambols in American Ethnic Literature. Berkeley: U of California P, 1997.

Vizenor, Gerald. Darkness in Saint Louis Bearheart. St. Paul: Truck P, 1978. Rpt. as Bearheart: The Heirship Chronicles. Minneapolis: $U$ of Minnesota P, 1990.

-. Griever: An American Monkey King in China. Minneapolis: $U$ of Minnesota P, 1987.

-. The Trickster of Liberty. Minneapolis: $U$ of Minneapolis P, 1988.

Wadlington, Warwick. The Confidence Game in American Literature. Princeton, NJ: Princeton, UP, 1975.

Willeford, William. The Fool and His Scepter: A Study in Clowns and Their Audience. Evanston, IL: Northwestern UP, 1969. 